Review/Meta-analyses

\title{
Illness representations among parents of children and adults with serious mental disorders: A systematic review and theoretical model
}

\author{
Ilanit Hasson-Ohayon ${ }^{\mathrm{a}, *}$, Gil Goldzweig ${ }^{\mathrm{b}}$, Adi Lavi-Rotenberg ${ }^{\mathrm{a}}$, David Roe ${ }^{\mathrm{c}, \mathrm{d}}$, \\ Gerdina Hendrika Maria Pijnenborge,f \\ a Department of Psychology, Bar-Ilan University, Ramat-Gan, Israel \\ b School of Behavioral Sciences, The Academic College of Tel-Aviv Yaffo, Israel \\ ${ }^{c}$ Department of Community Mental Health, Faculty of Social Welfare and Health Sciences, University of Haifa, Haifa, Israel \\ d Department of Clinical Medicine, Psychiatry, Aalborg University, Denmark \\ e GGZ Drenthe Mental Health Institute, Department of Psychotic Disorders, Assen, the Netherlands \\ ${ }^{\mathrm{f}}$ Department of Clinical Psychology and Experimental Psychopathology, University of Groningen, Groningen, the Netherlands
}

\section{A R T I C L E IN F O}

\section{Article history:}

Received 8 November 2018

Received in revised form 4 February 2019

Accepted 6 February 2019

Available online 12 February 2019

\section{Keywords:}

Illness perception

Parents

Insight

Self-stigma

\begin{abstract}
A B S T R A C T
Objective: Cognitive representations of an illness have an important impact on psychological outcomes. The current systematic review explored 1 ) the characteristics of illness representations held by parents of children and adults with serious mental illness (SMI), and 2) the associations of these representations with both parents' and patients' psychological outcomes.

Method: PSYINFO and PUBMED were screened for eligible studies published between January 2000 and August 2018. Selection was based on PRISMA guidelines. Reference lists of these papers were checked for additional references. Two independent coders extracted all relevant data.

Results: The search resulted in 31 relevant studies, which were divided, by type of methodology, into three sections: quantitative, qualitative, and mixed quantitative-qualitative. In each section, findings were divided in accordance with the two research questions.

Conclusion: Parents struggle to make meaning of their child's illness, often holding stigmatizing ideas about the illness and blaming themselves for its existence. More longitudinal studies that include both of the child's parents, as well as interventional studies, are needed to expand our knowledge of ways to help parents construct more beneficial representations of their children's illnesses.
\end{abstract}

(c) 2019 Elsevier Masson SAS. All rights reserved.

\section{Introduction}

One relatively recent development in the mental health field has been a shift in the way families of patients are viewed: that is, from being potential triggers of illness symptoms to being potential partners in the patients' recovery processes [1]. Although this shift has been evident mostly in child psychiatry, it has also expressed itself in adult mental health services. It began at the end of the 1950s when, due to historical changes in mental health legislation, social policy, and technological advances, responsibility for patients was largely given back to families. At that time, researchers began to explore the impact of mental illness on family members, and showed that coping with mental illness exerted a significant impact on them [2]. Research on family caregivers of individuals with serious mental illness (SMI) has shown that

\footnotetext{
* Corresponding author.

E-mail address: ilanit.hasson-ohayon@biu.ac.il (I. Hasson-Ohayon).
}

coping with a loved one's illness leads to burden and distress, and attempts have been made to identify the factors associated with this outcome. These factors include illness severity variables (e.g., number of hospitalizations), family environment and support $[3,4]$, and aspects related to illness representations, or the way in which family members think about and appraise the illness [5-7].

The current review focused on this last category of factors: parents' representations of their child's illness and the resultant associations with both parents' and patients' outcomes. Illness representations, which are based on personal experience as well as on available information from different resources both before and after diagnosis $[8,9]$, have previously been shown to be associated with parents' psychological outcomes. Thus, exploring these representations specifically among parents of children and adults with SMI is important for gaining an understanding of their psychological outcomes and the ways in which these outcomes can be improved. In addition, parents' illness representations also affect their children's outcomes [10], strengthening the need to further understand these representations in order to enhance children's adaptive outcomes. 
The current paper presents a review of papers that examined parents' representations of a child's illness - specifically, a child's mental illness - and the resultant associations with the parent's and/or child's outcome. The umbrella term "illness perception" refers to individuals' cognitive representations of and attitudes towards an illness [11,12]. This term is widely used in the field of health psychology [11] and has also recently been adopted in the mental health field. Illness perception includes perceptions of causes of, responsibility for, and outcomes of the illness [13]. Additional terms are more specific and relate to particular aspects of individuals' illness representations, such as self-stigma or internalized stigma, which refer to patients' internalization of stigmatizing views held by the public [14] as well as their parents' internalization of these views [6]. It should be noted that as selfstigma is highly related to self-esteem and self-confidence [14] it is an important construct to address. Another aspect is insight into the illness, which includes being aware of the illness label, the implications of this label, and the need for treatment. The topic of insight has been studied extensively among both patients [15-17] and among their parents [6,7]. Insight into the illness is also regarded here as an aspect of illness representations, although it is assumed to refer to one's level of awareness with regard to having the illness. However, the literature has suggested that clinical insight, at least aspects of it, might be better regarded as one's attitudes toward an illness rather than one's awareness of having the illness [17-19].

The purpose of this review was to address two major questions with regard to the illness representations held by parents of children and adults with SMI: 1) What characterizes these illness representations? 2) What is the relation of parents' illness representations with both parents' and patients' outcomes? The answers to these questions may have implications for intervention and therapy for parents who have a son or daughter with mental illness.

\section{Method}

\subsection{Literature search strategy}

The search method applied in this review was in line with PRISMA guidelines [20]. The following key words were used to identify relevant studies according to title and abstract fields: (Parents* OR mothers OR fathers) AND (insight OR self-stigma OR internalized stigma OR stigma OR illness perception* OR attribution* OR self-blame) AND (psychos* OR schizophrenia* OR mental illness* OR mental health OR mental disorder*) in the datasets PSYINFO and PUBMED. Limiters that were used were publication year (January 1, 2000 through August 31, 2018) and English language. It should be noted that we specifically used the words parents, mothers, and fathers as we wished to focus on this very particular population and not on family members in general.

Inclusion criteria were: 1) having a primary research question examining parents' illness representations; 2) containing an assessment of one of the constructs (i.e., illness perceptions, attitudes, attributions, self-stigma, insight) that signified illness representations in quantitative studies; or 3) containing an identified theme related to illness representations in qualitative studies. Thus, in order to be included in the review, papers needed to fulfill conditions 1 and 2 or conditions 1 and 3 .

\subsection{Study selection}

Due to shared difficulties and disabilities across different types of mental disorders [21,22], we assumed that similar challenges would be faced by parents of adults and children across different serious mental illnesses. We therefore included studies of parents of people with different types of SMI, e.g., psychoses, affective disorders, and OCD. We excluded studies of parents of patients with developmental disorders such as autism. In addition, as a large percentage of the identified studies included samples of mixed caretaking relatives, and not only parents, we included them as long as the percentage of parents in the sample was above $75 \%$.

Studies which focused on parents' perceptions of mental health services, their views regarding disclosing the illness, or their views regarding general health literacy were excluded. Although these parental perceptions are indeed related to parental perceptions of the illness, the focus of these perceptions was not the illness itself and therefore fell beyond the current review's aim.

\section{Results}

Table 1 presents the list of identified studies that used quantitative methods; Table 2 presents the list of identified studies that used qualitative methods; Table 3 presents the list of identified studies that used a mix of quantitative and qualitative methods. A total of 31 studies were identified in a screening process conducted by two independent judges (first and last authors) according to PRISMA guidelines [20], as can be seen in Fig. 1. During the first stage of screening the judges agreed on $82 \%$ of the articles, and during the second stage on $95 \%$ of the articles. Disagreements were resolved via discussion and a close reading of the relevant articles. For clarity, we presented the results separately for each table, and in each section (quantitative, qualitative, and mixed methodology) we divided the findings in accordance with the two research questions: illness perception characteristics, and illness perception characteristics' associations with outcomes.

\subsection{Findings from studies that used a quantitative methodology}

Twenty of the identified studies used a quantitative methodology, with half of them addressing different aspects of the illness perception construct, either general opinions regarding the illness or more specific aspects such as illness attribution and causality [23-31]. Eight studies addressed the construct of insight into the illness [6,7,32-37] and five studies addressed the parents' selfstigma $[6,7,9,37,38$. [It should be noted that a few of these studies addressed more than one relevant construct, e.g., they assessed both insight and self-stigma.

\subsubsection{Characteristics of illness perception among parents according to studies that used a quantitative methodology}

Studies that addressed illness perception showed mixed results regarding causality attribution. Moses [25] showed that parents tended to attribute the illness to biological/genetic factors, and almost half anticipated a good outcome in the future. Interestingly, Pottick and Davis [28] showed that mothers thought they bore less responsibility for their child's illness than clinicians attributed to them. Mothers who held their children responsible for their illnesses also seemed to hold their children responsible for recovering from their illnesses. In addition, Wong et al. [31] showed that most parents coping with early stages of the illness did not hold stigmatizing attitudes of the illness. They also showed a higher likelihood of adopting stigmatizing perceptions of the illness in the recent-onset stage than in the prodromal one. It should be noted that these parents endorsed associative stigma and felt they were stigmatized as parents of individuals with mental illness.

However, Vasconcelos et al. [30] showed that most parents, and mothers more than fathers, tended to blame themselves for overlooking their child's mental health problems and not responding properly (e.g., they viewed the existence of the illness as being related to them). When the child's illness was more 
Table 1

Studies that assessed parents' illness perception variables using a quantitative assessment methodology.

\begin{tabular}{|c|c|c|c|c|}
\hline $\begin{array}{l}\text { Authors, year of } \\
\text { publication, and } \\
\text { study's location }\end{array}$ & Sample & Study design & $\begin{array}{l}\text { Parents' illness perception } \\
\text { constructs that were } \\
\text { studied }\end{array}$ & Main findings \\
\hline $\begin{array}{l}\text { Brent et al., } 2011 \\
\quad \text { USA }\end{array}$ & $\begin{array}{l}13 \text { caregivers ( } 77 \% \text { parents) of } \\
\text { persons with early psychosis }\end{array}$ & $\begin{array}{l}\text { Cross-sectional } \\
\text { dyads of patients and } \\
\text { parents }\end{array}$ & Insight into the illness & $\begin{array}{l}\text { - Parents reported relatively high insight and had higher } \\
\text { awareness than patients in the domains of awareness of } \\
\text { having a mental illness and awareness of the psychosocial } \\
\text { consequences of illness. } \\
\text { - Agreement between parent and patient only in regard to } \\
\text { the need for medication, dimension of insight, and } \\
\text { awareness of symptoms. } \\
\text { - Parents' awareness was related to critical attitudes } \\
\text { toward patients. }\end{array}$ \\
\hline $\begin{array}{l}\text { Eaton et al., } 2018 \\
\quad \text { Australia }\end{array}$ & $\begin{array}{l}424 \text { parents of children with a } \\
\text { mental health disorder }\end{array}$ & $\begin{array}{l}\text { Cross-sectional, scale } \\
\text { development }\end{array}$ & Self-stigma & $\begin{array}{l}\text { Parents' self-stigma included three factors: self-blame, } \\
\text { self-shame, and "bad-parent" self-beliefs; all were } \\
\text { negatively correlated with self-esteem and } \\
\text { empowerment. }\end{array}$ \\
\hline $\begin{array}{l}\text { Fortune et al., } \\
2005 \\
\text { Ireland }\end{array}$ & $\begin{array}{l}42 \text { relatives ( } 93 \% \text { parents) of } \\
\text { patients diagnosed with } \\
\text { schizophrenia }\end{array}$ & Cross-sectional & $\begin{array}{l}\text { Illness perceptions, self- } \\
\text { blame, appraisals }\end{array}$ & $\begin{array}{l}\text {-Parents' self-blame and beliefs that they had control over } \\
\text { the child's psychosis were associated with higher distress. } \\
\text {-Perception of psychosis as chronic, of patient as having } \\
\text { stronger illness identity and consequences was associated } \\
\text { with more distress. } \\
\text {-Belief that the patient had control over the illness was } \\
\text { related to more distress, while beliefs in treatment having } \\
\text { control of psychosis was related to less distress } \\
\text { - Associations between aspects of illness perception and } \\
\text { distress were mediated by coping mechanisms. }\end{array}$ \\
\hline $\begin{array}{l}\text { Gaziel et al., } 2015 \\
\text { Israel }\end{array}$ & $\begin{array}{l}37 \text { parents of } 30 \text { adolescents } \\
\text { with psychiatric disorders }\end{array}$ & $\begin{array}{l}\text { Cross-sectional } \\
\text { dyads of patients and } \\
\text { parents }\end{array}$ & Insight into the disorder & $\begin{array}{l}\text {-Parental insight was positively correlated with the } \\
\text { adolescent's insight and self-stigma. } \\
\text {-Parental insight was negatively correlated with the two } \\
\text { dimensions of adolescent's subjective quality of life: } \\
\text { school and self. }\end{array}$ \\
\hline $\begin{array}{l}\text { Hasson-Ohayon } \\
\text { et al., } 2011 \\
\text { Israel }\end{array}$ & $\begin{array}{l}127 \text { parents of adults with } \\
\text { severe mental illness }\end{array}$ & Cross-sectional & $\begin{array}{l}\text { Insight into the illness } \\
\text { Self-stigma }\end{array}$ & $\begin{array}{l}\text { - Self-stigma among parents was found to mediate the } \\
\text { relationship between insight into a daughter's/son's } \\
\text { mental illness and family burden. } \\
\text { - Parents' awareness of the illness consisted of one } \\
\text { dimension that integrated aspects of awareness of the } \\
\text { label, the need for treatment, and the implications of the } \\
\text { illness. }\end{array}$ \\
\hline $\begin{array}{l}\text { Hasson-Ohayon } \\
\text { et al., } 2014 \\
\text { Israel }\end{array}$ & $\begin{array}{l}37 \text { parents of adolescents with } \\
\text { psychiatric disorders }\end{array}$ & Cross-sectional & $\begin{array}{l}\text { Insight into the illness } \\
\text { Self-stigma }\end{array}$ & $\begin{array}{l}\text { The positive association between insight and parental } \\
\text { stress was mediated by parents' self-stigma, suggesting } \\
\text { that insight increases self-stigma, which in turn increases } \\
\text { parental stress. }\end{array}$ \\
\hline $\begin{array}{l}\text { Hasson-Ohayon } \\
\text { et al., } 2017 \\
\text { Israel }\end{array}$ & $\begin{array}{l}70 \text { parents of children who were } \\
\text { hospitalized in an inpatient unit }\end{array}$ & Cross-sectional & Self-stigma & $\begin{array}{l}\text {-Self stigma moderated the effects of coping with } \\
\text { threatening information style. } \\
\text {-For parents with high self-stigma, more monitoring of } \\
\text { information was related to more burden. }\end{array}$ \\
\hline $\begin{array}{l}\text { Macgregor et al., } \\
2017 \\
\text { France }\end{array}$ & $\begin{array}{l}41 \text { parents of adults with } \\
\text { schizophrenia }\end{array}$ & $\begin{array}{l}\text { Cross-sectional } \\
\text { dyads of patients and } \\
\text { parents }\end{array}$ & Insight into the illness & $\begin{array}{l}\text {-Parents' correct attribution of symptoms to the illness (a } \\
\text { dimension of parental insight) was related to parents' } \\
\text { better cognitive performance and higher educational } \\
\text { levels. } \\
\text {-Parental knowledge about schizophrenia was not } \\
\text { associated with patient's insight. }\end{array}$ \\
\hline $\begin{array}{l}\text { Macgregor et al., } \\
2015 \\
\text { France }\end{array}$ & $\begin{array}{l}41 \text { parents of adults with } \\
\text { schizophrenia }\end{array}$ & $\begin{array}{l}\text { Cross-sectional } \\
\text { dyads of patients and } \\
\text { parents }\end{array}$ & Insight into the illness & $\begin{array}{l}\text {-Parents had higher insight than patients in all insight } \\
\text { dimensions. } \\
\text {-Adjusting to daily contact between patient and parent, } \\
\text { the effect of higher insight among parents disappeared } \\
\text { among those with frequent contact, excluding the } \\
\text { dimension of general awareness of the illness. }\end{array}$ \\
\hline $\begin{array}{l}\text { McNab et al., } \\
2007 \\
\text { Australia }\end{array}$ & $\begin{array}{l}53 \text { parents of young people with } \\
\text { first episode of psychosis }\end{array}$ & Cross-sectional & $\begin{array}{l}\text { Illness perception- } \\
\text { attribution of control }\end{array}$ & $\begin{array}{l}\text {-Attribution of control in illness to the patient was related } \\
\text { to higher criticism expressed by the parents toward the } \\
\text { patients. } \\
\text {-Attribution of control to the relatives was not related to } \\
\text { expressed emotion dimensions. }\end{array}$ \\
\hline $\begin{array}{l}\text { Moses, 2010a } \\
\text { USA }\end{array}$ & 60 parents of adolescents & $\begin{array}{l}\text { Cross-sectional dyads of } \\
\text { parents and patients }\end{array}$ & $\begin{array}{l}\text { Parents' perceptions of } \\
\text { controllability of the illness } \\
\text { and of the expected } \\
\text { outcome }\end{array}$ & $\begin{array}{l}\text {-The majority of parents attributed biological/genetic } \\
\text { reasons for } \\
\text { their child's illness. } \\
-43 \% \text { of the parents agreed or strongly agreed that their } \\
\text { child would have a good outcome in the future. } \\
\text {-Greater parental optimism regarding outcome and } \\
\text { greater perception of the adolescent as being able to } \\
\text { control his/her mental health problems were associated } \\
\text { with adolescents' decreased self-stigma. }\end{array}$ \\
\hline $\begin{array}{l}\text { Onwumere et al., } \\
2017 \\
\text { UK }\end{array}$ & $\begin{array}{l}68 \text { carers ( } 92.5 \% \text { parents) of } \\
\text { persons with first episode of } \\
\text { psychosis }\end{array}$ & $\begin{array}{l}\text { longitudinal- } \\
\text { intervention assessment } \\
\text { (CBT group intervention } \\
\text { for carers) }\end{array}$ & Illness perception/beliefs & $\begin{array}{l}\text {-Significant positive shifts in beliefs about the perceived } \\
\text { consequences of } \\
\text { the illness for the patient and relatives, in attributions of } \\
\text { blame to relatives and patient, and overall coherent } \\
\text { understanding of the illness (coherence). }\end{array}$ \\
\hline
\end{tabular}


Table 1 (Continued)

\begin{tabular}{|c|c|c|c|c|}
\hline $\begin{array}{l}\text { Authors, year of } \\
\text { publication, and } \\
\text { study's location }\end{array}$ & Sample & Study design & $\begin{array}{l}\text { Parents' illness perception } \\
\text { constructs that were } \\
\text { studied }\end{array}$ & Main findings \\
\hline & & & & $\begin{array}{l}\text {-Carers' confidence in dealing with difficulties increased } \\
\text {-No significant changes were observed in carer beliefs re } \\
\text { the control they had over the illness. }\end{array}$ \\
\hline $\begin{array}{l}\text { Peterson \& } \\
\text { Docherty, } 2004 \\
\text { USA }\end{array}$ & $\begin{array}{l}54 \text { parents of young adults with } \\
\text { schizophrenia }\end{array}$ & Cross-sectional & Self-blame & $\begin{array}{l}\text { - Parents who perceived the illness etiology as their } \\
\text { responsibility had higher emotional over- involvement } \\
\text { ratings than non-self-blaming parents. }\end{array}$ \\
\hline $\begin{array}{l}\text { Pottick \& Davis, } \\
2001 \\
\text { USA }\end{array}$ & $\begin{array}{l}102 \text { mothers of youth with } \\
\text { mental health problems }\end{array}$ & $\begin{array}{l}\text { Cross-sectional (parents } \\
\text { sample compared to } \\
\text { clinicians sample) }\end{array}$ & $\begin{array}{l}\text { Attribution of causal and } \\
\text { solution responsibility to } \\
\text { the patient }\end{array}$ & $\begin{array}{l}\text {-Mothers made less attribution of causal responsibility to } \\
\text { themselves than clinicians did. } \\
\text {-No significant differences were found between mothers } \\
\text { and professionals re: the degree of etiological } \\
\text { responsibility that the child bore. } \\
\text {-Attributing causal responsibility to the patient was } \\
\text { related to the attribution of solution responsibility. }\end{array}$ \\
\hline $\begin{array}{l}\text { Raffard et al., } \\
2014 \\
\text { France }\end{array}$ & $\begin{array}{l}37 \text { parents of persons with } \\
\text { schizophrenia }\end{array}$ & $\begin{array}{l}\text { Cross-sectional dyads of } \\
\text { patients and parents }\end{array}$ & $\begin{array}{l}\text { Insight into the illness, } \\
\text { cognitive insight }\end{array}$ & $\begin{array}{l}\text {-Parents' and patients' cognitive insight were correlated } \\
\text {-Parents' cognitive insight and clinical insight were } \\
\text { correlated. } \\
\text {-Parents' awareness of patient's symptoms (dimension o } \\
\text { clinical insight) was associated with lower levels of } \\
\text { overconfidence in one's beliefs and with cognitive insigh } \\
\text { total score, as well as with cognitive performance. }\end{array}$ \\
\hline $\begin{array}{l}\text { Shanley \& Reid, } \\
2015 \\
\text { Australia }\end{array}$ & $\begin{array}{l}487 \text { parents of young children } \\
\text { with mental health problems }\end{array}$ & Cross-sectional & Illness perception & $\begin{array}{l}\text {-More severe problems were correlated with the } \\
\text { perception of a longer timeline, a more cyclical timeline } \\
\text { more severe consequences, and more emotional } \\
\text { representations. } \\
\text {-Parents of children with more severe externalizing } \\
\text { problems (rather than internalizing problems) were more } \\
\text { likely to see their child as being able to control of the } \\
\text { problem and to have a less coherent understanding of the } \\
\text { illness. }\end{array}$ \\
\hline $\begin{array}{l}\text { Vasconcelos } \\
\text { et al., } 2017 \\
\text { UK }\end{array}$ & $\begin{array}{l}80 \text { relatives ( } 80 \% \text { parents) of } \\
\text { people with recent-onset } \\
\text { psychosis }\end{array}$ & Cross-sectional & $\begin{array}{l}\text { Attribution of self-blame } \\
\text { (assessed in mixed } \\
\text { quantitative and qualitative } \\
\text { methods) }\end{array}$ & $\begin{array}{l}\text {-Greater self-blame was associated with relatives' } \\
\text { increased distress. } \\
\text {-Adjusting for patient age, self-blame attributions were } \\
\text { not predictive of relatives' distress. } \\
\text {-Most relatives blamed themselves for overseeing their } \\
\text { family member's mental health problems improperly, and } \\
\text { they perceived themselves generally as poor carers. } \\
\text {-Female relatives scored higher than males on self-blame }\end{array}$ \\
\hline $\begin{array}{l}\text { Wong et al., } 2009 \\
\text { USA }\end{array}$ & $\begin{array}{l}11 \text { carers (95\% parents) of } \\
\text { persons with prodromal } \\
\text { symptoms }(n=9) \text { and first } \\
\text { episode }(n=11)\end{array}$ & Cross-sectional & $\begin{array}{l}\text { Opinions about mental } \\
\text { illness }\end{array}$ & $\begin{array}{l}\text {-Parents tended not to endorse general stigmatizing } \\
\text { attitudes toward the illness, with more parental } \\
\text { endorsement of people in the prodromal stage in } \\
\text { comparison to the recent onset stage. } \\
\text {-Associative stigma (being stigmatized as a parent of a } \\
\text { person with mental illness) was endorsed more by family } \\
\text { members of patients with recent-onset psychosis than by } \\
\text { family members of prodromal individuals. } \\
\text {-No association between associative } \\
\text { stigma and subjective or objective family burden was } \\
\text { found. }\end{array}$ \\
\hline $\begin{array}{l}\text { Zisman-Ilani } \\
\text { et al., } 2013 \\
\text { Israel }\end{array}$ & $\begin{array}{l}194 \text { parents of persons with } \\
\text { serious mental illness (SMI) }\end{array}$ & $\begin{array}{l}\text { Cross-sectional } \\
\text { psychometric } \\
\text { assessment of scale }\end{array}$ & Self-stigma & $\begin{array}{l}\text { - Parents' version of the self-stigma scale consisted of } \\
\text { three factors: discrimination experiences, social } \\
\text { withdrawal and alienation, and stereotype endorsement } \\
\text {-Parents' scored highest on the stereotype endorsement } \\
\text { factor and lowest on the discrimination factor. } \\
\text { - Parents of persons with SMI endorsed the common } \\
\text { negative stereotypes regarding mental illness. }\end{array}$ \\
\hline $\begin{array}{l}\text { Zisman-Ilani } \\
\text { et al., } 2017 \\
\text { Israel }\end{array}$ & $\begin{array}{l}162 \text { Israeli mothers of a person } \\
\text { with SMI ( } 95 \text { were Jewish and } \\
67 \text { were Arab). }\end{array}$ & Cross-sectional & $\begin{array}{l}\text { Parental insight into the } \\
\text { illness and self-stigma }\end{array}$ & $\begin{array}{l}\text { - Self-stigma was found to mediate the relationship } \\
\text { between insight and burden among Jewish mothers and } \\
\text { not among Arab mothers. } \\
\text { - Among the Arab mothers no association between insigh } \\
\text { into the illness and self-stigma was found. }\end{array}$ \\
\hline
\end{tabular}


Table 2

Studies that assessed parents' illness perception variables using a qualitative assessment methodology.

\begin{tabular}{|c|c|c|c|c|}
\hline $\begin{array}{l}\text { Authors, year of } \\
\text { publication, and } \\
\text { study's location }\end{array}$ & Sample & Study design & $\begin{array}{l}\text { Parents' illness perception } \\
\text { themes that were studied }\end{array}$ & Main findings \\
\hline $\begin{array}{l}\text { Darmi et al., } 2017 \\
\text { Greece }\end{array}$ & $\begin{array}{l}16 \text { parents of children with } \\
\text { psychotic disorders }\end{array}$ & $\begin{array}{l}\text { Cross- } \\
\text { sectional } \\
\text { retrospective }\end{array}$ & $\begin{array}{l}\text {-In search of meaning } \\
\text {-Perceived guilt }\end{array}$ & $\begin{array}{l}\text {-Parents' perceptions of illness changed over time: at first they } \\
\text { normalized the prodromal symptoms and viewed the illness as } \\
\text { temporary, then viewed it as having an unpredictable outcome, } \\
\text { attributing the illness to themselves, biological factors, } \\
\text { psychosocial factors, or a spiritual experience. } \\
\text {-The changes in illness perception led to a redefinition of the } \\
\text { parent-child relationship. } \\
\text {-Parents experienced profound guilt for causing the disorder or } \\
\text { not preventing the disorder. } \\
\text { - Dedication to the child's care at the parents' own expense } \\
\text { helped parents overcome their guilt. }\end{array}$ \\
\hline $\begin{array}{l}\text { Eaton et al., } 2016 \\
\quad \text { Australia }\end{array}$ & $\begin{array}{l}11 \text { mothers of children with } \\
\text { psychiatric disorders }\end{array}$ & $\begin{array}{l}\text { Cross- } \\
\text { sectional }\end{array}$ & Self-stigma & $\begin{array}{l}\text {-Mothers who internalized the public stigma mentioned feeling } \\
\text { like a "bad parent." }\end{array}$ \\
\hline $\begin{array}{l}\text { Ferriter \& Huband, } \\
2003 \\
\text { UK }\end{array}$ & $\begin{array}{l}\text { Parents of } 22 \text { adult patients } \\
\text { diagnosed with schizophrenia }\end{array}$ & $\begin{array}{l}\text { Cross- } \\
\text { sectional }\end{array}$ & $\begin{array}{l}\text { Views on causes of } \\
\text { schizophrenia }\end{array}$ & $\begin{array}{l}\text {-Biological and life-event theories accounting for the etiology of } \\
\text { schizophrenia were rated by parents as most familiar and } \\
\text { important. } \\
\text {-Parents were the least aware of outdated pathological parenting } \\
\text { theories than other explanation. }\end{array}$ \\
\hline $\begin{array}{l}\text { Hickman et al., } \\
2016 \\
\text { UK }\end{array}$ & $\begin{array}{l}\text { Six parents of young people who } \\
\text { had been } \\
\text { hospitalized with early psychosis }\end{array}$ & $\begin{array}{l}\text { Cross- } \\
\text { sectional }\end{array}$ & $\begin{array}{l}\text { Attribution of illness to } \\
\text { the patients' } \\
\text { responsibility or external } \\
\text { factors }\end{array}$ & $\begin{array}{l}\text {-Holding the patient, or external factors, responsible for the } \\
\text { illness. } \\
\text {-Those who didn't blame the patient showed better } \\
\text { differentiation between the illness and the patient. }\end{array}$ \\
\hline $\begin{array}{l}\text { Hyun et al., } 2017 \\
\text { South Korea }\end{array}$ & $\begin{array}{l}10 \text { mothers of adults with } \\
\text { schizophrenia }\end{array}$ & $\begin{array}{l}\text { Cross- } \\
\text { sectional }\end{array}$ & $\begin{array}{l}\text {-Becoming part of the } \\
\text { socially weak } \\
\text {-Becoming a mentally ill } \\
\text { person }\end{array}$ & $\begin{array}{l}\text {-Experience of stigma led to a transformation into a negative } \\
\text { sense of self-identity, mothers attributed the illness to } \\
\text { themselves and viewed patients and family members of persons } \\
\text { with mental illness as part of the "socially weak." }\end{array}$ \\
\hline $\begin{array}{l}\text { Wong \& Poon, } 2002 \\
\text { Hong-Kong }\end{array}$ & $\begin{array}{l}12 \text { parents of persons with } \\
\text { schizophrenia }\end{array}$ & $\begin{array}{l}\text { Cross- } \\
\text { sectional }\end{array}$ & $\begin{array}{l}\text { Attributing symptoms to } \\
\text { personality problems }\end{array}$ & $\begin{array}{l}\text {-Attributing control of symptoms to the patients, viewing the } \\
\text { symptoms as personality characteristics, seemed to be related to } \\
\text { negative communications patterns }\end{array}$ \\
\hline $\begin{array}{l}\text { Lautenbach et al., } \\
2012 \\
\text { USA }\end{array}$ & $\begin{array}{l}9 \text { mothers of persons with mental } \\
\text { illness who also coped with other } \\
\text { disorders in the family }\end{array}$ & $\begin{array}{l}\text { Cross- } \\
\text { sectional }\end{array}$ & $\begin{array}{l}\text { Perceived manifestation of } \\
\text { illness, perceived } \\
\text { chronicity and outcome }\end{array}$ & $\begin{array}{l}\text {-Mothers perceived serious mental illness as more devastating } \\
\text { and unexpected than physical conditions, as having a negative } \\
\text { outcome, as being chronic, as affecting others beyond the } \\
\text { patient, as having stigma (and therefore receiving less support), } \\
\text { and as leading to loss of patient's personality. } \\
\text {-Mothers also expressed the possible attribution of the illness to } \\
\text { themselves. }\end{array}$ \\
\hline $\begin{array}{l}\text { Shpinger et al., } \\
2013 \\
\text { Israel }\end{array}$ & $\begin{array}{l}10 \text { parents of adult children who } \\
\text { were coping with psychiatric } \\
\text { illness }\end{array}$ & $\begin{array}{l}\text { Cross- } \\
\text { sectional } \\
\text { (retrospective) }\end{array}$ & $\begin{array}{l}\text { Perception of sudden } \\
\text { onset }\end{array}$ & $\begin{array}{l}\text {-Parents perceived the illness diagnosis as a traumatic event that } \\
\text { forced them to acknowledge the seriousness of the child's } \\
\text { condition and to change their inner schema of the child and their } \\
\text { relationship with him/her. } \\
\text {-Almost all of the parents described the onset of the illness as } \\
\text { sudden. }\end{array}$ \\
\hline
\end{tabular}

In studies assessing parental insight, parents showed a high awareness of the illness. They also showed insight into the illness label and illness consequences more than did the patients [32]. Similarly, Macgregor et al. [34] showed that parents displayed a higher level of insight than did patients on all dimensions, but their insight was not related to their knowledge of the illness [35]. Parents of adults with SMI tended to have greater insight into the illness and higher self-stigma than did parents of adolescents with SMI [6,7], possibly due to the fact that the illness had been going on longer.

To conclude, the studies listed in Table 1 provide cause for optimism, as parents seemed to be aware of the biological models of mental illness, and causal attribution was not evident in all of the studies. Yet, some studies did show a tendency towards self-blame and stigmatizing perceptions of the illness, presumably dependent on the severity of the disorders and the time since diagnosis.

\subsubsection{Parental illness perception association with parents' and patients' outcomes according to studies that used a quantitative methodology}

With regard to the associations between illness perception characteristics and parental outcome, it was shown that parents' distress was associated with parents' belief that patients had control over their illnesses [23]. Parents' distress was also associated with higher parental criticism toward patients [24]. Belief in treatment control however, was associated with lower parental distress [23]. In addition, parents who attributed both illness cause and control to themselves showed higher distress $[23,30]$ and emotional involvement [27] than did parents who did not make such attributions. It should be noted that in one study this effect disappeared when patients' age was controlled for [30], possibly due to the adjustment process. It should also be noted that higher parental education and higher parental cognitive abilities were associated with higher levels of insight [34].

Parental insight into the illness was positively related to parents' critical attitudes toward the patient [32], family burden [6] and parental distress [7]. This effect was mediated by parental selfstigma [6,7], with one study suggesting that this mediation was culturally dependent and occurred mostly in Western cultures [37]. Parents' self-stigma was negatively related to parents' self-esteem and empowerment [39]. Parental insight was also found to be positively correlated with parents' cognitive performance and cognitive insight [36]. With regard to patient outcomes, studies showed that parental insight was negatively correlated with quality of life among adolescents with mental disorders in the domains of 
Table 3

Studies that assessed parents' illness perception variables using a mixed qualitative and quantitative assessment methodology.

\begin{tabular}{|c|c|c|c|c|}
\hline $\begin{array}{l}\text { Authors, year of } \\
\text { publication, and } \\
\text { study's location }\end{array}$ & Sample & $\begin{array}{l}\text { Study } \\
\text { design }\end{array}$ & $\begin{array}{l}\text { Parents' illness perception } \\
\text { constructs/ identified themes } \\
\text { that were studied }\end{array}$ & Main findings \\
\hline $\begin{array}{l}\text { Czuchta et al., } \\
2001 \\
\text { Canada }\end{array}$ & $\begin{array}{l}20 \text { parents of a child that was } \\
\text { hospitalized }\end{array}$ & $\begin{array}{l}\text { Cross- } \\
\text { sectional }\end{array}$ & $\begin{array}{l}\text {-Evolving change in the } \\
\text { meaning of the illness } \\
\text {-Stigmatized attitudes } \\
\text { toward the illness } \\
\text {-Uncertainty of the illness } \\
\text { existence }\end{array}$ & $\begin{array}{l}\text {-Parents struggled to find meaning in changes of the illness and to } \\
\text { understand the causes of those symptomatic changes. } \\
\text {-Stigmatized attitudes towards mental illness were associated } \\
\text { with burden } \\
\text {-Parents' higher education was related to increased } \\
\text { acknowledgment of the illness and less uncertainty. }\end{array}$ \\
\hline $\begin{array}{l}\text { Moses 2010b } \\
\text { USA }\end{array}$ & $\begin{array}{l}\text { Parents or legal guardians of } 70 \\
\text { adolescents diagnosed with one or } \\
\text { more mental disorders }\end{array}$ & $\begin{array}{l}\text { Cross- } \\
\text { sectional }\end{array}$ & $\begin{array}{l}\text {-Parental self-blame for the } \\
\text { illness } \\
\text {-Parents' perception of } \\
\text { stigma }\end{array}$ & $\begin{array}{l}\text { - } 40 \% \text { of parents were inclined to blame themselves and attributed } \\
\text { the etiology of the illness to themselves. } \\
\text {-Parental self-blame was associated with parents' poorer } \\
\text { psychological well-being. } \\
\text {-The common reasons for parental self-blame included perceiving } \\
\text { themselves as bad, passing on "bad genes," providing a negative } \\
\text { family environment, and ineffective oversight of their child's } \\
\text { mental health status. } \\
\text {-Parents' perceptions of stigmatization were related to greater } \\
\text { parental self-blame. These associations largely diminished when } \\
\text { parents' perceptions of family support were taken into account. }\end{array}$ \\
\hline $\begin{array}{l}\text { Wasserman et al., } \\
2010 \\
\text { USA }\end{array}$ & $\begin{array}{l}36 \text { parents of adults with } \\
\text { schizophrenia (compared to } 13 \\
\text { parents of adults with autism) }\end{array}$ & $\begin{array}{l}\text { Cross- } \\
\text { sectional }\end{array}$ & Attribution of illness & $\begin{array}{l}\text {-The majority of parents from both groups attributed the cause of } \\
\text { schizophrenia to genetics. } \\
\text { - Parents of adults diagnosed with autism/Asperger's disorder } \\
\text { tended to make less blameworthy attributions towards patients } \\
\text { than did parents of adults diagnosed with schizophrenia. }\end{array}$ \\
\hline
\end{tabular}

school and self [33]. Parental optimism and parental perception of the patient as being able to control his/her mental health problems was negatively correlated with adolescent patients' self-stigma [25].

Only one study in this systematic review was interventional and assessed the effects of a psychoeducational group intervention for parents of individuals who had experienced a recent episode of psychosis [26]. The aim of the study was to assess changes in illness beliefs, and findings supported the effectiveness of the intervention in creating a more coherent understanding of the illness, a more positive perception with regard to perceived consequences for the patient and relative, and a lower perception of blame for the parents. There was no change in beliefs regarding the parent being able to control the illness [26].

Integrating the findings of the quantitative studies, it seems that attributing control to the patient or the parent increases burden whereas attributing control to treatment is beneficial. In addition, depending on the time since diagnosis and the individual 's specific culture, having insight into the medical model of illness leads to self-stigma. Psychoeducational interventions seem effective in helping individuals adopt a positive perception of illness consequences. With regard to parental illness perception and a child's outcome, studies showed that parental insight negatively affected the child's quality of life. But parental perception of patient's having control over the illness was beneficial in terms of reduced self-stigma.

\subsection{Findings from studies that used a qualitative methodology}

Eight of the studies in this systematic review used a qualitative methodology. These studies used interviews and content analysis to explore themes related to the ways parents perceived the illness. The majority of these studies discussed themes related to perceived causes of the illness, whereas a smaller number of studies focused on other aspects of illness perception and resultant associations with outcome.

3.2.1. Characteristics of illness perception among parents according to studies that used a qualitative methodology

Findings showed diversity in parents' ideas regarding the perceived causes of their child's illness, and included parents' blaming themselves, parents' blaming the patients, biological explanations, and life events or spiritual experiences as triggers [40-43]. Although one study showed that most of the participating parents endorsed biological or life events as causes [41], other studies showed that parents blamed themselves for causing their child's disorder $[40,44]$ and perceived themselves as "bad parents" [45]. The onset of the illness was perceived as sudden and traumatic and as changing the cognitive schema of the child from a "normal child" to other representations [46]. A mental illness, in comparison to a physical illness, was shown to be perceived by the parent as more devastating, unexpected, chronic, stigmatizing, and leading to the loss of the patient's organic personality [43]. It should be noted that parents' perceptions of their child's illness have been shown to change over time, ranging from their normalizing of the illness in the prodromal stage to seeing the illness as having an unpredictable outcome in the more chronic stages [40].

\subsubsection{Parental illness perceptions' association with parents' and patients' outcomes according to studies that used a qualitative methodology}

Themes that were found in the qualitative studies suggested that illness perception was related to a redefinition of the parentchild relationship $[40,46]$. A parental perception of the patient as being responsible for his/her illness was related to less parental differentiation between the patient and the illness [42] and to more negative parent-patient communication [47]. In addition, parents who blamed themselves for their child's illness were able to overcome this self-blame to some extent by dedicating themselves to their child's care at their own expense [40].

\subsection{Findings from studies that used a mixed-methods methodology}

Three of the studies in this systematic review used both quantitative and qualitative methods. These studies were focused on stigmatizing perceptions and attribution of illness cause.

\subsubsection{Characteristics of illness perception among parents according to} studies that used a mixed-methods methodology

Czuchta \& McCay [48] showed that parents struggled to find meaning in the changes that took place over the course of the 


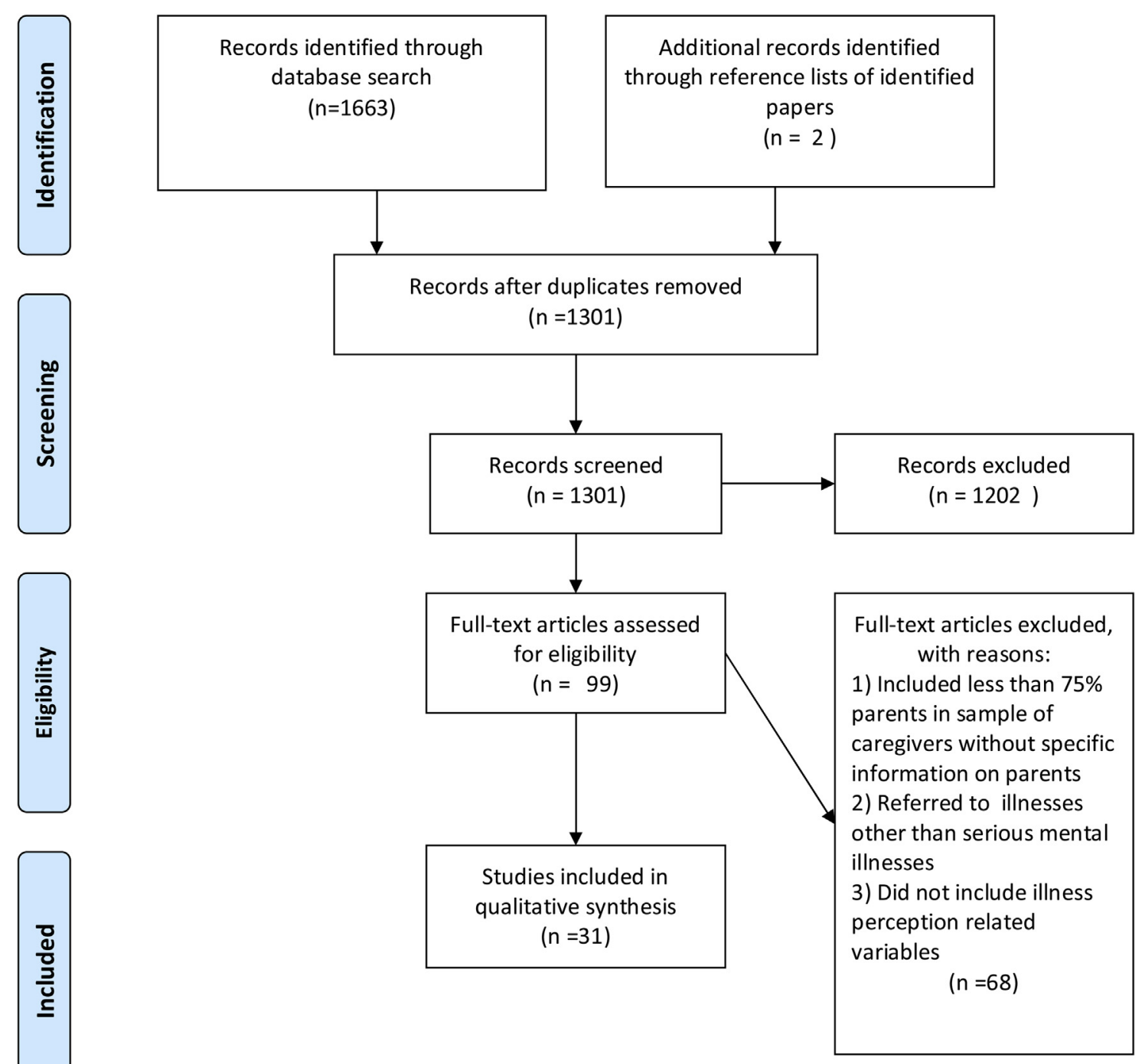

Fig. 1. PRISMA Flow Diagram- selection of studies for the systematic review.

illness and in trying to understand these changes. Moses [10] showed that $40 \%$ of the participating parents in her study were inclined to self-blame; that is, they viewed themselves as being responsible for the illness's etiology. Common reasons for parents ' self-blame were being perceived as a "bad parent," passing on "bad genes," providing a negative familial environment, and inappropriately overseeing their child's mental health problems. This self-blame was associated with perceiving the illness in a stigmatizing way [10]. An additional study showed that the majority of parents made a genetic attribution and that in comparison to parents of patients with autism, parents of patients with schizophrenia tended to be more blaming of the patients [49].

\subsubsection{Parental illness perception association with parents' and} patients' outcomes according to studies that used a mixed-methods methodology

Stigmatizing attitudes toward SMI were positively related to parental burden [48] and to parental self-blame [10]. Importantly, social support seemed to diminish the effect of the self-blame aspect of stigmatization [10]. Parents' level of education was positively related to their knowledge of the illness [48].

\subsection{Integration of findings}

An integration of the findings in this review, with regard to the process of constructing illness representations, is suggested in Fig. 2. Parental illness representations of a child's psychiatric illness seem to be based on the knowledge available to them (i.e., both information that is medical in nature and information that can best be termed stigmatizing). These associations between available knowledge and illness representations seem to be moderated by three categories of variables: illness characteristics, patient's characteristics, and parent's characteristics. For example, when symptoms are severe it may result in a high association between stigmatizing attitudes and perceiving the illness as having an unfavorable outcome. Another example is that when parents have low cognitive abilities, their ability to process the knowledge at their disposal is negatively affected; the result is a low association between available knowledge and illness representations.

This process of constructing illness representations is also subject to change over time as levels of insight and self-stigma seem to be higher among parents of adult patients than young patients. In addition, aspects of illness perception also seem to 


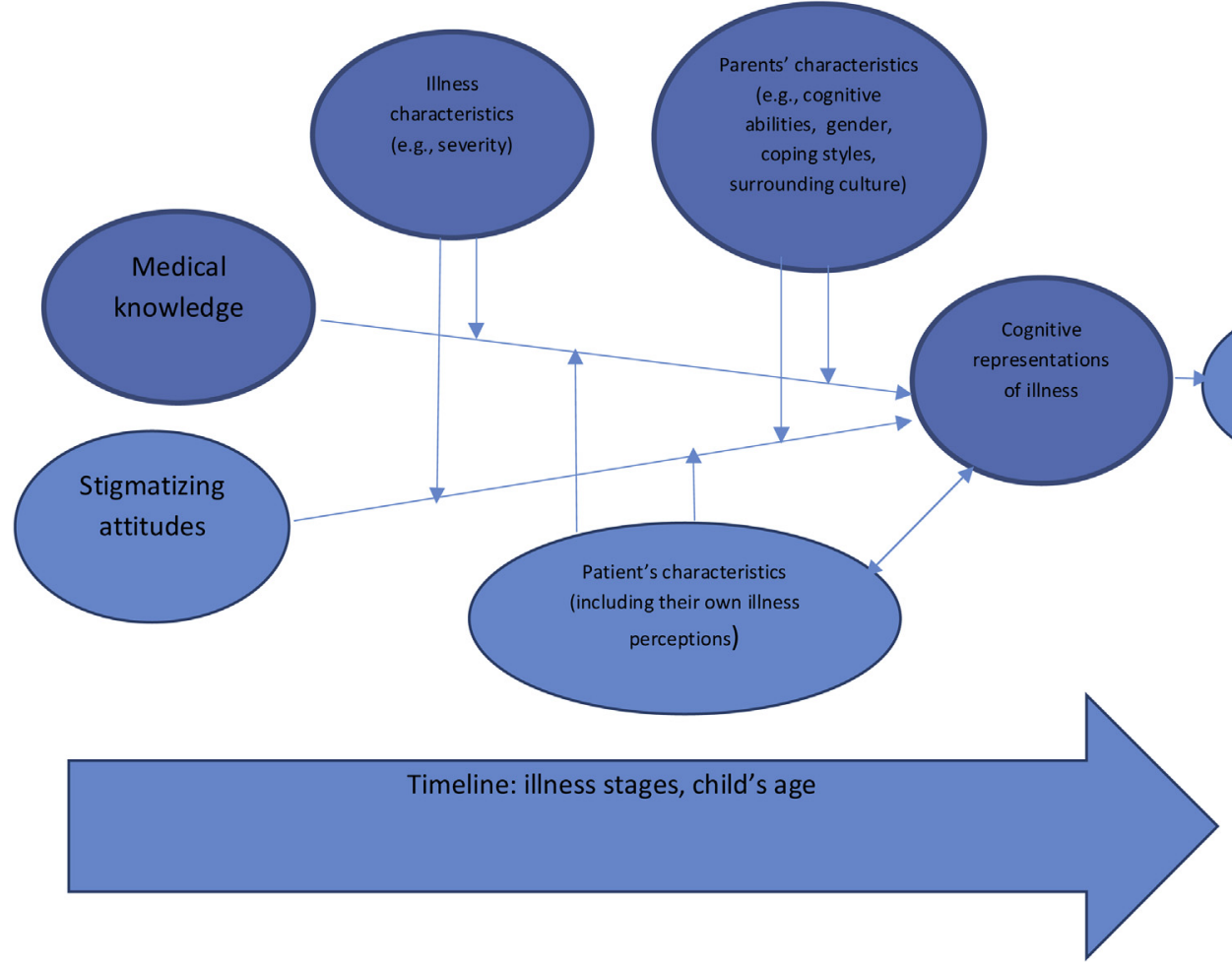

Fig. 2. The construction of illness representations among parents of children and adults with SMI.

change according to stages of the illness. It should be noted that the proposed model was developed on the basis of findings that supported only some aspects of the construction process. The process as a whole remains to be validated.

\section{Discussion}

Although illness perceptions and related variables have been extensively studied in the health psychology literature, these constructs have received less systematic attention in the familialparental context in psychiatry (note a recent review [50] on patients' perceptions). The current systematic review aimed to summarize the existing literature on illness perceptions held by parents of individuals with SMI, exploring both characteristics and outcomes of illness perceptions. The review included studies that assessed constructs related to illness perceptions such as selfstigma, insight, and attitudes.

4.1. Characteristics of the cognitive representations of illness held by parents of children and adults with SMI

With regard to our first question - that is, what characterizes the illness perceptions held by parents of children and adults with SMI? - the findings showed that these parents' illness representations included several dimensions related to etiology, controllability, and outcome. These dimensions were often conceptualized as causal attributions of illness (e.g., genetic, environmental, familial) and responsibility both for the illness's existence and its outcome (e.g., attributing blame to patients or parents) $[23,25,41]$. In addition to these dimensions, the parents' illness representations also related to their level of acceptance of the illness label (referred to as insight into the illness) and the internalization of stigmatizing aspects of the illness, also referred to as self-stigma [7,39]. The dimensions characterizing these parents' illness representations were similar to the dimensions characterizing illness perceptions in the field of general medicine [51] and among patients in psychiatry $[13,52]$. The dimensions also seemed to be consistent over time; that is, they were relevant for parents of children with SMI as well as for parents of adults with SMI [27,29], and for parents of patients at different stages of illness (e.g., first episode) [24]. Importantly, these dimensions also seemed to be consistent across cultures (e.g., in the U.S [27], in Australia [29], in South Korea [44], in Hong Kong [47]) and emerged spontaneously in qualitative interviews $[42,43]$.

Studies were inconsistent with regard to which causes and consequences were more present in the parents' illness representations. Although some studies showed that most of the parents tended to blame themselves for their child's illness [40], others showed that most parents endorsed a genetic biological attribution $[25,41]$. Similarly, there was an inconsistency in the perception of outcome; specifically, it seemed that parents could be divided into those who anticipated a positive outcome in the future versus those who did not [25]. These perceptions were related both to one's knowledge of the illness (sometimes referred to as insight) and to one's internalization of stigmatizing attitudes. Studies also varied with regard to findings regarding insight and self-stigma levels. Interestingly, the level of both insight and self-stigma seemed to be lower among parents of adolescents with SMI than among parents of adults with SMI [6,7], and associative stigma seemed to be higher in parents of individuals with recent onset than in parents of children at the prodromal stage [31]. In addition, the association between insight and self-stigma tended to be culturally dependent, with insight being more associated with self-stigma only among relatively Western cultures in comparison to more traditional ones [37]. As such, it may be that parents' attributions of causes, control, and outcome are related to different stages of the illness, different ages of the children, and different cultures. It seems that although biological explanations are more available today than in the past, adhering to the medical model of mental illness leads to more 
stigmatizing attitudes that consist of self-blame and perceived negative consequences and that the self-blame and negative perceptions increase over time.

Most of the studies that addressed these cognitive representation aspects were cross-sectional. One qualitative study addressed illness perception in retrospect and showed that parental perceptions changed over time from aiming to normalize the prodromal symptoms and viewing the illness as temporary, to viewing the illness as having an unpredictable outcome, blaming the illness on themselves (the parents), on biological factors, on psychosocial factors, or on a spiritual experience [40]. Another study utilized a quantitative assessment of a CBT psychoeducation intervention; this study showed how the intervention was beneficial in producing positive shifts in the following areas: beliefs about the perceived consequences of the illness for the patient and relatives, attributions of blame to relatives and patients, and a coherent understanding of the illness [26].

When assessing illness representations, a number of studies adopted a dyadic approach and compared the parents' perceptions with those of the patients or clinicians. Brent et al. [32] showed that parents had greater insight (across a few insight dimensions) than did patients, and Pottick and Davis [28] showed that mothers tended to blame themselves for their child's SMI more than clinicians blamed them. Additional comparative perspectives showed that parents viewed SMIs as: more devastating and unexpected than physical conditions; having negative outcomes; being chronic; affecting other individuals beyond the patient; having a stigma attached to them (and therefore being the recipients of less support); and leading to the loss of the patient's organic personality [43]. Another comparative study suggested that parents of adults diagnosed with schizophrenia tended to blame the patients for their illness more than did parents of adults diagnosed with autism/Asperger's disorder [49]. This finding is in line with the concept of a "stigma hierarchy," and suggests that SMI is one of the most stigmatizing illnesses [53].

In conclusion, based on the reviewed studies it seems that parents struggle to make meaning of their child's illness and to construct cognitive perceptions of this illness [48]. Presumably, they construct these perceptions on the basis of information that is accessible to them, both the medical facts and the impressions (sometimes stigmatizing) that other people have of the illness. The effect that this information has on parents' cognitive perceptions of the illness seems to be moderated by illness characteristics (e.g., severity of illness) [29]; parent's characteristics (e.g., coping-withinformation style) [9], and patient's characteristics, including their own illness perceptions (e.g., patient's self-stigma) [33]. Fig. 2 describes this theoretical model of illness representation construction. It should be noted that the proposed process is also influenced by the timeline of the illness trajectory and age.

\subsection{Associations between the cognitive representations of the illness} and patients' and parents' outcomes

According to the reviewed studies, the way parents think about their child's illness affects their own and the patient's psychological outcome. Specifically, with regard to parents' outcome, it was shown that a greater awareness of the illness label seemed to be related to greater family burden [6,7], and to the parent's more critical attitude toward the patient [32]. The parents' internalization of stigma was shown to mediate the effect on burden [6,7], and to be positively related to parental self-blame [10] and negatively related to self-esteem and empowerment [39]. In addition, parents' perceptions that the illness was caused by them (the parents), that it was chronic, that it affected identity, and that patients could control their illnesses, were found to be related to more parental distress [23]. Parents' self-blame was also found to be related to higher criticism toward the patients [24], higher emotional over-involvement [27], higher distress [30], and poor psychological well-being [10].

With regard to the association between parents' cognitive representations of the illness and patients' outcomes, very few studies were identified. One study showed that high parental insight was related to higher patient self-stigma and lower patient quality of life across a few dimensions [33], suggesting that the endorsement of the medical model by the parent (see recent discussion of insight as agreement with the medical model by Hasson-Ohayon [19]), may lead to negative outcomes for the patient. In addition, Moses [25] showed that greater parental optimism regarding outcome and greater parental perception of the patient as being able to control his/her mental health problems were associated with decreased patient self-stigma. Additional studies addressing the effects of parents' illness representations on the relationship between patient and parent showed the following: parents were able to overcome their self-blame to some extent by dedicating themselves to their child's care at their own expense [40]; blaming the patient was related to less differentiation between the patient and the patient's illness [42]; and blaming the patient was related to poorer communication between patient and parent [47]. Changes in illness perception were shown to be related to changes in the relationship and the need to redefine the parentchild relationship $[40,46]$.

Thus, although limited, findings on the effects of parents' illness representations do exist. These findings mostly show that these representations may have implications for both parent and patient $[10,33]$ and suggest that ways of coping with medical information should be taken into account when assessing the impact of insight and stigma internalization [9]. In addition, attributions of selfblame seem to have negative implications for parents' well-being and distress, as well as for parent-child relationships [27,40].

\subsection{Conclusions, limitations, and future directions}

Different attempts have been made to examine the illness representations held by parents of children and adults with SMI. A few of these attempts have included adapted illness perception scale from the context of general medicine to the context of psychiatry, for both patients and parents [13]. However, given that most studies used mixed samples of carers (i.e., not only parents), there is little information on its application among parents only. Other attempts have included the exploration of specific aspects of illness representations, such as insight into the illness, self-stigma, and causal attributions. These studies mostly used patient scales that had been adapted for parents, with the exception of Eaton et al. [39], who suggested that parents' self-stigma should be conceptualized differently than patient's self-stigma, and that an appropriate scale for parents should focus on self-blame, shame, and parental beliefs that the parent is a "bad parent."

One of the main findings of these studies is that parents tend to endorse stigmatizing beliefs and blame themselves for their child's illness, although attributing blame to the patient and external factors also exists. In addition, it seems that parents struggle with finding meaning in the illness, and they tend to construct this meaning on the basis of available knowledge, illness characteristics, their own characteristics, and patient's characteristics, a process depicted in Fig. 2. The proposed model still requires support as, to date, studies have only provided a limited amount of support for some aspects of it. Further studies are also needed to explore the effects of parents' illness representations on outcome, as limited data exist on this subject as well. Most of the studies that were reviewed showed that self-blame was related to negative psychological outcomes among parents and that parents endorsed stigmatizing attitudes toward the illness. These findings call for both social anti-stigmatizing 
interventions [54] and specific interventions for parents. For example, adapting Narrative Enhancement and Cognitive Therapy (NECT) for the reduction of self-stigma [55] may be helpful in reducing parents' endorsement of stigmatizing information.

In this review, there was a lack of longitudinal and interventional studies. Only one study in this review showed the benefits yielded by a psychoeducation intervention in the positive changing of illness perception dimensions [26], and an additional study addressed illness perception retrospectively [40]. In addition, the studies in this review were not screened for their level of quality due to limited resources. It should also be mentioned that there are relevant variables that were not explicitly addressed by the reviewed studies, such as substance use, which might impact the perception of cause and controllability. Also, adopting a recovery model, as opposed to a medical model, might very well influence illness representations, and was an issue not addressed in this review. More studies are needed to expand our understanding of effective ways to help parents reconstruct the representations they hold of their child's illness. One example might be the application of NECT, described above, and additional ones might include personal one-on-one therapy that takes into account the parents' coping-with-information style and additional parental characteristics that influence the way illness representations are created. Specifically, it was shown that for parents with high self-stigma, more monitoring of information was related to more burden [9], suggesting that gaining more information on the illness should be tailored appropriately and should be sought after reducing self-stigma.

In addition to utilizing a longitudinal approach and examining the proposed model of constructing illness representations, it is also recommended to include both of the child's parents in future studies. Based on a systems theory approach [56], one would expect to see not only a parent-child influence in the process of constructing illness meaning, one would also expect to see a parent-parent influence. As no available studies on this aspect of the topic exist, exploring it in future studies using a dyadic approach would further contribute to the theoretical model of constructing illness representations.

\section{Disclosure of interest}

The authors declare that they have no competing interests.

\section{References}

[1] Gehart DR. The mental health recovery movement and family therapy, part i: consumer-led reform of services to persons diagnosed with severe mental illness. J Marital Fam Ther 2012;38(3):429-42.

[2] Maurin JT, Boyd CB. Burden of mental illness on the family: a critical review. Arch Psychiatr Nurs 1990;4(2):99-107.

[3] Grandón P, Jenaro C, Lemos S. Primary caregivers of schizophrenia outpatients: burden and predictor variables. Psychiatry Res 2008;158(3):335-43.

[4] Awad AG, Voruganti LN. The burden of schizophrenia on caregivers. Pharmacoeconomics 2008;26(2):149-62.

[5] Kallert TW, Nitsche I. Assessing the opinions of relatives on the causes and social consequences of different mental disorders: are instruments crossculturally valid? Psychiatry Res 2008;158(3):344-55.

[6] Hasson-Ohayon I, Levy I, Kravetz S, Vollanski-Narkis A, Roe D. Insight into mental illness, self-stigma, and the family burden of parents of persons with a severe mental illness. Compr Psychiatry 2011;52(1):75-80.

[7] Hasson-Ohayon I, Tuval-Mashiach R, Morag-Yaffe M, Gaziel M, Schapir L, Zalsman G, et al. Parents of adolescents with psychiatric disorders: insight into the disorder, self-stigma and parental stress. Compr Psychiatry 2014;55 (5):1106-10.

[8] Jun WH, Park JS, Jeong AS. The effect of education program by illness on perception of illness and knowledge of medication in psychiatric inpatients. West J Nurs Res 2011;17(2):110-6.

[9] Hasson-Ohayon I, Pijnenborg GHM, Ben-Pazi A, Taitel S, Goldzweig G. Coping with information style and family burden: possible roles of self-stigma and hope among parents of children in a psychiatric inpatient unit. Eur Psychiatry 2007;42:8-13.

[10] Moses T. Exploring parents' self-blame in relation to adolescents' mental disorders. Fam Relat 2010;59(2):103-20.
[11] Broadbent E, Petrie KJ, Main J, Weinman J. The brief illness perception questionnaire. J Psychosom Res 2006;60(6):631-7.

[12] Frostholm L, Fink P, Christensen KS, Toft T, Oernboel E, Olesen F, et al. The patients' illness perceptions and the use of primary health care. Psychosom Med 2005;67(6):997-1005.

[13] Lobban F, Barrowclough C, Jones S. Assessing cognitive representations of mental health problems. II. The illness perception questionnaire for schizophrenia. Br J Clin Psychol 2005;44(2):163-79.

[14] Livingston JD, Boyd JE. Correlates and consequences of internalized stigma for people living with mental illness: a systematic review and meta-analysis. Soc Sci Med 2010;71(12):2150-61.

[15] Hasson-Ohayon I, Kravetz S, Meir T, Rozencwaig S. Insight into severe mental illness, hope, and quality of life of persons with schizophrenia and schizoaffective disorders. Psychiatry Res 2009;167(3):231-8.

[16] Lysaker PH, Roe D, Yanos PT. Toward understanding the insight paradox: internalized stigma moderates the association between insight and social functioning, hope, and self-esteem among people with schizophrenia spectrum disorders. Schizophr Bull 2007;33(1):192-9.

[17] Lincoln TM, Lüllmann E, Rief W. Correlates and long-term consequences of poor insight in patients with schizophrenia. A systematic review. Schizophr Bull 2007;33(6):1324-42.

[18] Lysaker PH, Pattison ML, Leonhardt BL, Phelps S, Vohs JL. Insight in schizophrenia spectrum disorders: relationship with behavior, mood and perceived quality of life, underlying causes and emerging treatments. World Psychiatry 2018;17(1):12-23.

[19] Hasson-Ohayon I. Overlap and distinction between measures of insight and self-stigma. Psychiatry Res 2018;266:47-64.

[20] Moher D, Liberati A, Tetzlaff J, Altman DG. Preferred reporting items for systematic reviews and meta-analyses: the PRISMA statement. Ann Intern Med 2009;151(4):264-9.

[21] Iyer SN, Rothmann TL, Vogler JE, Spaulding WD. Evaluating outcomes of rehabilitation for severe mental illness. Rehabil Psychol 2005;50(1):43.

[22] Kessler RC, Barker PR, Colpe LJ, Epstein JF, Gfroerer JC, Hiripi E, et al. Screening for serious mental illness in the general population. Arch Gen Psychiatry 2003;60(2):184-9.

[23] Fortune DG, Smith JV, Garvey K. Perceptions of psychosis, coping, appraisals, and psychological distress in the relatives of patients with schizophrenia: an exploration using self-regulation theory. Br J Clin Psychol 2005;44(3):319-31.

[24] McNab C, Haslam N, Burnett P. Expressed emotion, attributions, utility beliefs, and distress in parents of young people with first episode psychosis. Psychiatry Res 2007;151(1-2):97-106.

[25] Moses T. Adolescent mental health consumers' self-stigma: associations with parents' and adolescents' illness perceptions and parental stigma. J Commun Psychol 2010;38(6):781-98.

[26] Onwumere J, Glover N, Whittaker S, Rahim S, Chu Man L, James G, et al Modifying illness beliefs in recent onset psychosis carers: evaluating the impact of a cognitively focused brief group intervention in a routine service. Early Interv Psychiatry 2017.

[27] Peterson EC, Docherty NM. Expressed emotion, attribution, and control in parents of schizophrenic patients. Psychiatry 2004;67(2):197-207.

[28] Pottick KJ, Davis DM. Attributions of responsibility for children's mental health problems: parents and professionals at odds. Am J Orthopsychiatry 2001;71 (4):426-35.

[29] Shanley DC, Reid GJ. The impact of parents' illness representations on treatment acceptability for child mental health problems. J Emot Behav Disord 2005;23(2):115-27.

[30] Vasconcelos e Sa D, Barrowclough C, Hartley S, Wearden A. Self-blame attributions in relatives of people with recent-onset psychosis: associations with relatives' distress and behavioural control. Br J Clin Psychol 2017;56 (2):172-88

[31] Wong C, Davidson L, Anglin D, Link B, Gerson R, Malaspina D, et al. Stigma in families of individuals in early stages of psychotic illness: family stigma and early psychosis. Early Interv Psychiatry 2009;3(2):108-15.

[32] Brent BK, Giuliano AJ, Zimmet SV, Keshavan M, Seidman LJ. Insight into illness in patients and caregivers during early psychosis: a pilot study. Schizophrenia Res 2011;127(1-3):100-6.

[33] Gaziel M, Hasson-Ohayon I, Morag-Yaffe M, Schapir L, Zalsman G, Shoval G. Insight and satisfaction with life among adolescents with mental disorders: assessing associations with self-stigma and parental insight. Eur Psychiatry 2015;30(2):329-33.

[34] Macgregor A, Norton J, Bortolon C, Robichon M, Rolland C, Boulenger JP, et al. Insight of patients and their parents into schizophrenia: exploring agreement and the influence of parental factors. Psychiatry Res 2015;228 (3):879-86

[35] Macgregor A, Norton J, Raffard S, Capdevielle D. Is there a link between biological parents' insight into their offspring's schizophrenia and their cognitive functioning, expressed emotion and knowledge about disorder? Compr Psychiatry 2017;76:98-103.

[36] Raffard S, Bortolon C, Macgregor A, Norton J, Boulenger JP, El Haj M, et al. Cognitive insight in schizophrenia patients and their biological parents: a pilot study. Schizophrenia Res 2014;159(2-3):471-7.

[37] Zisman-Ilani Y, Hasson-Ohayon I, Levy-Frank I, Tuval-Mashiach R, Roe D. Selfstigma, insight, and family burden among Israeli mothers of people with serious mental illness: ethno-national considerations. Transcult Psychiatry 2017;54(3):423-41. 
[38] Zisman-Ilani Y, Levy-Frank I, Hasson-Ohayon I, Kravetz S, Mashiach-Eizenberg $\mathrm{M}$, Roe D. Measuring the internalized stigma of parents of persons with a serious mental illness: the factor structure of the parents' internalized stigma of mental illness scale. J Nerv Ment Dis 2013;201(3):183-7.

[39] Eaton K, Ohan JL, Stritzke WG, Corrigan PW. The parents' self-stigma scale: development, factor analysis, reliability, and validity. Child Psychiatry Hum Dev 2018;1-12.

[40] Darmi E, Bellali T, Papazoglou I, Karamitri I, Papadatou D. Caring for an intimate stranger: parenting a child with psychosis. J Psychiatr Ment Health Nurs 2017;24(4):194-202.

[41] Ferriter M, Huband N. Experiences of parents with a son or daughter suffering from schizophrenia. J Psychiatr Ment Health Nurs 2003;10(5):552-60.

[42] Hickman G, Newton E, Fenton K, Thompson J, Boden ZV, Larkin M. The experiential impact of hospitalisation: parents' accounts of caring for young people with early psychosis. Clin Child Psychol Psychiatry 2016;21(1):145-55.

[43] Lautenbach DM, Hiraki S, Campion MW, Austin JC. Mothers' perspectives on their child's mental illness as compared to other complex disorders in their family: insights to inform genetic counseling practice. J Genet Couns 2012;21 (4):564-72.

[44] Hyun MS, Cho Chung HI, Kim H. Experiences of family stigma among mothers of adult children with mental illness in South Korea. Issues Ment Health Nurs 2017;38(10):845-51.

[45] Eaton K, Ohan JL, Stritzke WG, Corrigan PW. Failing to meet the good parent ideal: self-stigma in parents of children with mental health disorders. J Child Fam Stud 2016;25(10):3109-23.

[46] Shpigner E, Possick C, Buchbinder E. Parents' experience of their child's first psychiatric breakdown: "Welcome to hell". Soc Work Health Care 2013;52 (6):538-57.
[47] Wong DFK, Poon WL. Factors influencing expressed emotion found between Chinese caregivers and their relatives with schizophrenia in Hong Kong. Social work in mental health. .

[48] Czuchta DM, McCay E. Help-seeking for parents of individuals experiencing a first episode of schizophrenia. Arch Psychiatr Nurs 2001;15(4):159-70.

[49] Wasserman S, Weisman de Mamani A, Mundy P. Parents' criticisms and attributions about their adult children with high functioning autism or schizophrenia. Autism 2010;14(2):127-37.

[50] Carter L, Read J, Pyle M, Morrison AP. The impact of causal explanations on outcome in people experiencing psychosis: a systematic review. Clin Psychol Psychother 2017;24(2):332-47.

[51] Leventhal H, Benjamin Y, Brownlee S, Diefenbach M, Leventhal EA, PatrickMiller L, Robitaille C, et al. Illness representations; Theoretical foundations. In: Petrie KJ, Weinman J, editors. Perceptions of health and illness. London: Harwood Academic Publishers; 1997.

[52] Barrowclough C, Lobban F, Hatton C, Quinn J. An investigation of models of illness in carers of schizophrenia patients using the Illness Perception Questionnaire. Br J Clin Psychol 2001;40(4):371-85.

[53] Thomas A. Stability of Tringo's hierarchy of preference toward disability groups: 30 years later. Psychol Rep 2000;86:1155-6.

[54] Corrigan PW, Miller FE. Shame, blame, and contamination: a review of the impact of mental illness stigma on family members. J Ment Health 2004;13 (6):537-48.

[55] Yanos PT, Roe D, Lysaker PH. Narrative enhancement and cognitive therapy: a new group-based treatment for internalized stigma among persons with severe mental illness. Int J Group Psychother 2011;61(4):576-95.

[56] Minuchin P. Families and individual development: Provocations from the field of family therapy. Child Dev 1985;289-302. 